\title{
Upcycling Phosphorus Recovered from Anaerobically Digested Dairy Manure to Support Production of Vegetables and Flowers
}

\author{
Katherine K. Porterfield ${ }^{1}$, Robert Joblin ${ }^{2}$, Deborah A. Neher ${ }^{3,4}{ }^{(\mathbb{D}}$, Michael Curtis ${ }^{5}$, \\ Steve Dvorak ${ }^{6}$, Donna M. Rizzo ${ }^{4,7}$, Joshua W. Faulkner ${ }^{3,8}$ and Eric D. Roy ${ }^{1,4, *(D)}$ \\ 1 Rubenstein School of Environment and Natural Resources, University of Vermont, \\ Burlington, VT 05405, USA; katherine.k.porterfield@uvm.edu \\ 2 Magic Dirt Horticultural Products, LLC, Little Rock, AR 72223, USA; bob@cenergy.us \\ 3 Department of Plant \& Soil Science, University of Vermont, Burlington, VT 05405, USA; \\ deborah.neher@uvm.edu (D.A.N.); joshua.faulkner@uvm.edu (J.W.F.) \\ 4 Gund Institute for Environment, University of Vermont, Burlington, VT 05405, USA; drizzo@uvm.edu \\ 5 CDT Tech, Inc., Columbia, CT 06489, USA; mike@cannadevtech.com \\ 6 DVO, Inc., Chilton, WI 53014, USA; SteveD@dvoinc.com \\ 7 Department of Civil \& Environmental Engineering, University of Vermont, Burlington, VT 05405, USA \\ 8 Extension Center for Sustainable Agriculture, University of Vermont, Burlington, VT 05405, USA \\ * Correspondence: eroy4@uvm.edu
}

Received: 22 December 2019; Accepted: 31 January 2020; Published: 5 February 2020

\begin{abstract}
Dissolved air flotation (DAF) separates phosphorus (P)-rich fine solids from anaerobically digested dairy manure, creating opportunities to export surplus $P$ to the marketplace as a bagged plant food product. Seedlings of tomato and marigold were amended at various volume per volume $(v / v)$ ratios with plant foods consisting of fine solids upcycled (i.e., transformed into a higher quality product) by drying and blending with other organic residuals. A plate competition assay was conducted to assess the fine solids' potential to suppress the plant pathogen Rhizoctonia solani. Plant foods were comprised of $2.0-2.1 \% \mathrm{~N}, 0.8-0.9 \% \mathrm{P}$ and $0.6-0.8 \% \mathrm{~K}$. Extractions indicated that plant foods contained a mixture of plant-available and slow-release P. At $6 \% v / v$ plant food, dry biomass of marigold and tomato were six-times greater than the unamended control and not significantly different from a market alternative treatment. Fine solids exhibited negligible potential to suppress $R$. solani. This study indicates that DAF-separated fine solids could be used to support horticulture, providing information for design of a circular economy approach to dairy manure nutrient management. Life cycle assessment and business model development for this nutrient recovery strategy are necessary next steps to further guide sustainability efforts.
\end{abstract}

Keywords: nutrient recovery; waste valorization; organics recycling; circular economy

\section{Introduction}

Phosphorus $(\mathrm{P})$ is an essential nutrient for plant growth that is mined from a limited and non-renewable supply of phosphate rock [1]. At the same time, much of the P used in agriculture is accumulating in watersheds as legacy $\mathrm{P}$ and transported to the aquatic environment where it causes eutrophication and associated water quality impairment [2]. Recovering and reusing excess $P$ from agricultural waste streams (e.g., manure) in a more circular economy could address both sustainable management of $\mathrm{P}$ resources as well as the environmental externalities associated with $\mathrm{P}$ loss from agriculture [3-7]. Some policymakers have sought to catalyze P recovery and recycling efforts in recent 
years as part of nutrient stewardship efforts. In the United States, this includes the ongoing Vermont Phosphorus Innovation Challenge [8], which aims to identify one or more technologies that:

1. Capture, and ideally reuse, $\mathrm{P}$, reducing the risk of pollution to waterways,

2. Convert collected dairy manure or other organic wastes to energy, recycled fertilizers, or other products,

3. Determine the amount of state support required for these projects to be viable.

Anaerobic digestion is an increasingly common manure management strategy for reducing greenhouse gas emissions and generating renewable energy in the form of biogas [9,10]. However, anaerobic digestion alone falls short of addressing nutrient management issues associated with conventional dairy production [11]. Digestate-the byproduct of anaerobic digestion-is rich in $\mathrm{P}$ and other nutrients [12], but can typically only be applied to land in close proximity to where it is generated due to its high moisture content [11]. Not unlike undigested manure [13,14], repeated land application of digestate may have adverse effects on air and water quality [15], limiting the long-term sustainability of anaerobic digestion if direct local land application is the sole management option for digestate [16].

Increasingly, there is interest in concentrating nutrients from digested animal manure in more transportable and marketable forms to facilitate movement of $P$ from areas where soils have sufficient or excess $P$ to other P-limited fields or the marketplace [11,17]. Primary solid-liquid separation via screw press is commonly used to separate the coarse solids from digestate, creating solid and liquid fractions with distinct characteristics $[12,18,19]$. The coarse solids have value as animal bedding, commercial potting mixes (e.g., Magic Dirt ${ }^{\mathrm{TM}}$ ), and mushroom cultivation substrates [20,21], and can be recycled on-farm, or sold off-farm to reduce P surpluses on dairy farms and ameliorate the cost of nutrient recovery. However, primary solid-liquid separation via screw press only captures about a third of the $\mathrm{P}$ contained in digestate in the more transportable solid fraction, with the rest remaining in the liquid fraction [12].

Emerging advanced nutrient recovery technologies provide the opportunity to recover $\mathrm{P}$ that is not captured by primary solid-liquid separation via screw press. Dissolved air flotation (DAF) recovers the majority of $\mathrm{P}$ from the post-screw press liquid digestate fraction by flocculating and separating the P-rich secondary fine solids [22]. DAF-separated fine solids have been shown to contain $85 \pm 12 \%$ of the $P$ in post-screw press dairy manure digestate [23] and also have a lower moisture content (e.g., $20.4 \pm 3.0 \%$ total solids) than manure or pre-separation digestate (e.g., $4.1 \pm 0.3 \%$ total solids), making transportation more economically feasible on- and off-farm [23]. With most of the $P$ removed - the remaining liquid effluent has a higher N:P ratio that more closely matches crop needs, making it more appropriate to use on-farm without adding excess $P$ to soils [22,23].

While the technology to recover the majority of $\mathrm{P}$ from digestate is available, sufficient market incentives do not yet exist to facilitate widespread implementation of this practice [11,24]. One possible solution is to upcycle (i.e., transform into a higher quality product) DAF-captured fine solids into a commercial plant food that can be sold in smaller units (e.g., $<10 \mathrm{~kg}$ bags) at higher price per $\mathrm{kg}$ of material than can be obtained for bulk products. A model of a theoretical integrated dairy-cropland system in which manure $P$ is recovered, upcycled and exported to the marketplace is shown in Figure 1. 


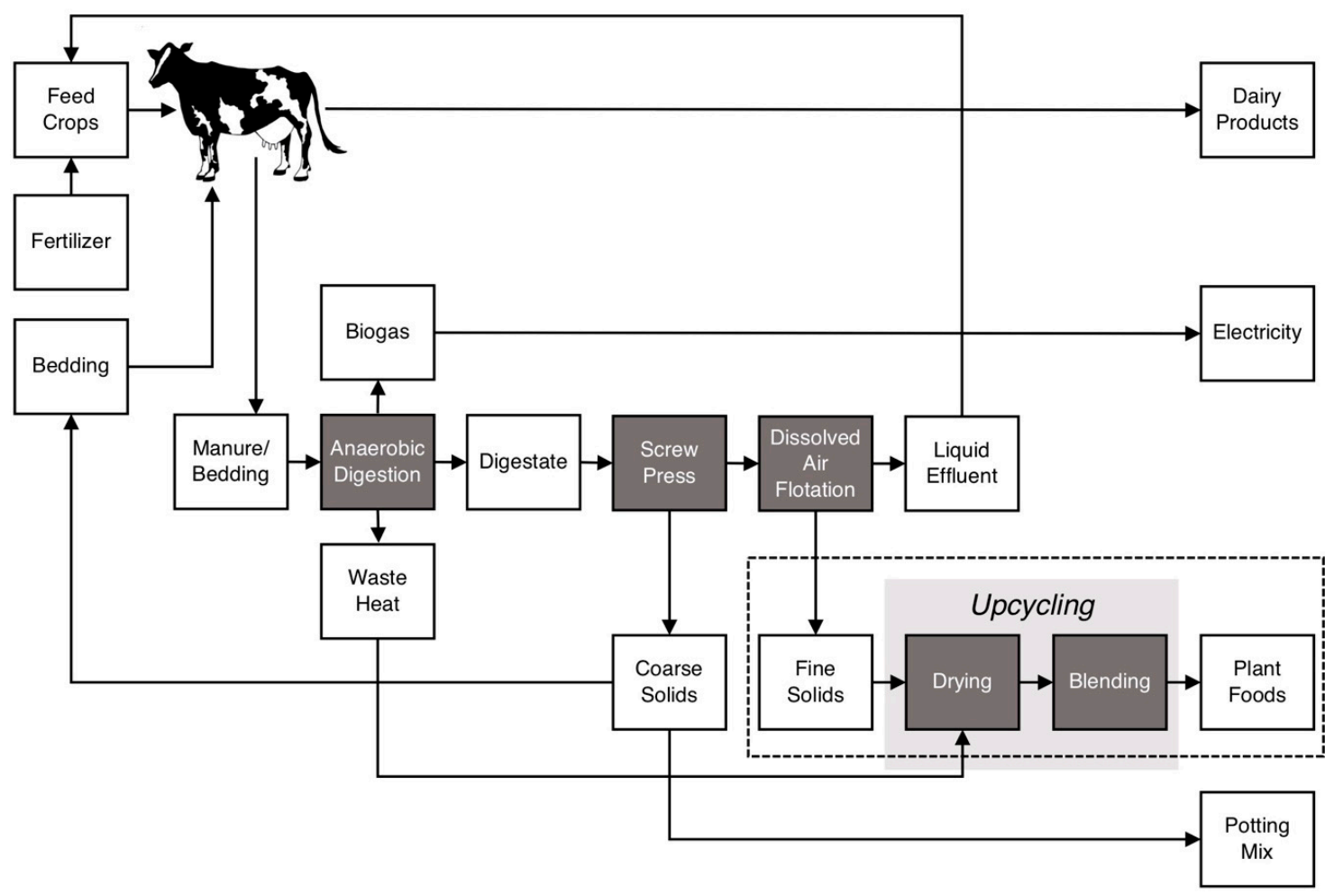

Figure 1. Diagram of nutrient and energy fluxes through a theoretical integrated dairy-cropland system using dissolved air flotation and upcycling to recover and recycle fine solids from manure digestate. White boxes depict nutrient and energy stocks and grey boxes depict processes. Arrows represent nutrient and energy fluxes. The dotted line box indicates the components investigated in this study. Adapted from Porterfield et al. (2020).

Horticultural production requires high inputs of the essential plant macronutrients $\mathrm{N}, \mathrm{P}$ and $\mathrm{K}$ and therefore presents a potential market for a plant food made from P-rich DAF-captured fine solids. Previous studies have demonstrated that fine solids recovered from dairy manure digestate can provide fertilization value in potato [25] and tomato [26] production, and both solid and liquid manure digestate materials have exhibited potential to suppress Rhizoctonia solani and other phytopathogenic fungi $[20,27]$. Additional agronomic benefits have been linked to the organic carbon (C) fraction of digestate, which may act as a biostimulant $[28,29]$ in addition to contributing stable $C$ to soils [30]. This suggests that DAF-captured fine solids may have substantial value as an input for horticultural production of vegetables and flowers. In addition to providing economic incentive for P recovery and reuse, sales of DAF-captured fine solids could also create a new revenue stream for dairy farms.

We conducted a seedling bioassay to assess the agronomic potential of two novel plant foods made by blending partially dried fine solids captured by DAF with other organic residuals. The objectives of our study were to:

1. Determine if plant foods made from DAF-captured fine solids provide fertilization without inhibiting germination in horticultural applications,

2. Determine which plant food recipes and application rates work best for tomato and marigold seedlings,

3. Assess the pathogen suppression potential of DAF-captured fine solids. 


\section{Materials and Methods}

\subsection{Plant Food Design}

The methodology described below is outlined in Figure 2. Our team, including academic researchers and industry experts in nutrient recovery and products for horticultural use, designed two plant foods consisting of DAF-captured fine solids blended with a dairy manure-derived biochar and/or a dried distiller's grain and dried whey permeate formulation. Fine solids were collected from a DAF system fed by post-screw press effluent from a plug-flow anaerobic digester accepting $>95 \%$ dairy manure feedstock at Blue Spruce Farm in Bridport, Vermont, USA. The dried distiller's grain and whey permeate formulation is a patented soil amendment made by Magic Dirt ${ }^{\mathrm{TM}}$ and has a guaranteed analysis of $3 \% \mathrm{~N}, 0.5 \% \mathrm{P}$ and $0.75 \% \mathrm{~K}$. The manure-derived biochar is a commercially available soil conditioner produced by Magic Dirt ${ }^{\mathrm{TM}}$ and is made by pyrolyzing raw manure at $650{ }^{\circ} \mathrm{C}$ for about $60 \mathrm{~min}$. It has a guaranteed analysis of $0.5 \% \mathrm{~N}, 0.5 \% \mathrm{P}$ and $2 \% \mathrm{~K}$.

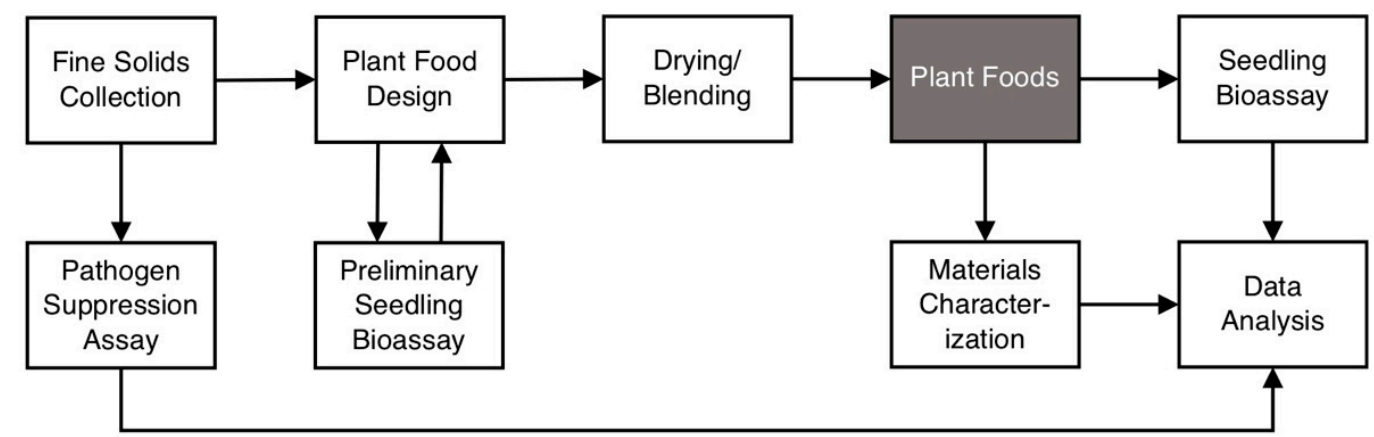

Figure 2. Diagram of methodology used in the present study.

Preliminary experimentation with plant food recipes using as-is fine solids indicated significant, positive fertilization effects for tomatoes, peppers, marigolds and petunias without compromising germination. However, we experienced difficulty blending the as-is fine solids (17\% total solids) with other materials and observed possible mechanical inhibition of plant growth due to surface caking. These factors-along with the transportation and storage limitations imposed by still relatively high moisture content-necessitated drying the fine solids prior to blending. For this study, plant foods were prepared using fine solids from Blue Spruce Farms dried in an oven at $60{ }^{\circ} \mathrm{C}$ to achieve $45 \%$ total solids, a degree of drying thought to be feasible in practice by our private industry team members. Two plant foods were prepared using recipes informed by results from the preliminary experimentation with as-is fine solids, which indicated that plant foods containing biochar produced the greatest tomato biomass and plant foods without biochar produced the greatest marigold biomass (data not shown). The revised plant food recipes and volume per volume $(v / v)$ application rates trialed in the present study are reported in Table 1.

Table 1. Plant food recipes and bioassay application rates.

\begin{tabular}{cccccc}
\hline Plant Food & $\begin{array}{c}\text { DAF-Captured } \\
\text { Fine Solids (\%) }\end{array}$ & $\begin{array}{c}\text { Dried Distiller's Grain \& } \\
\text { Dried Whey Permeate } \\
\text { Formulation (\%) }\end{array}$ & Biochar (\%) & Plants Tested & $\begin{array}{c}\text { Application Rates } \\
(\% \boldsymbol{v} / v)\end{array}$ \\
\hline Plant Food A & 95 & 5 & 0 & Marigold & $0,2,4,6,8$ \\
Plant Food A & 90 & 10 & 0 & Marigold & 6 \\
Plant Food A & 85 & 15 & 0 & Marigold & 6 \\
Plant Food B & 93 & 5 & 2 & Tomato & $0,2,4,6,8,10,12$ \\
\hline
\end{tabular}

\subsection{Seedling Bioassay}

We conducted a bioassay of tomato (Solanum lycopersicum L.; 'Celebrity F1') and marigold (Tagetes patula; 'Janie Spry') seeds fertilized with plant food recipes and application rates informed by 
results from the preliminary experimentation with as-is fine solids (data not shown). Plant foods were incorporated into a professional grade peat+perlite (75:25) soilless substrate (ProMix BX) at 0, 2, 4, 6 and $8 \% v / v$ Plant Food A for marigolds and $0,2,4,6,8,10$, and 12\% v/v Plant Food B for tomatoes. Two additional modifications of the Plant Food A recipe were tested for marigolds at $6 \% v / v$ : partially dried fine solids blended with $10 \% v / v$ dried distiller's grain and whey permeate formulation (Plant Food $\mathrm{A}_{1}$ ) and $15 \% v / v$ dried distiller's grain and whey permeate formulation (Plant Food $\mathrm{A}_{2}$ ). A market alternative plant food (Miracle-Gro ${ }^{\circledR}$ Nature's Care ${ }^{\circledR}$ Organic and Natural Vegetable, Fruit and Flower Food) was also tested at the recommended application rate of $2 \% v / v$ as a positive control.

One seed (Harris Seeds, Rochester, NY) was sown in each cell of trays made by cutting 128-cell germination trays (Greenhouse Megastore Item No. CN-PLG, $25.1 \mathrm{~mL}^{-1}{ }^{-1}$ ) into eight parts. Six 16-cell trays per plant-amendment-application rate combination were arranged in a randomized block design on a single greenhouse bench at the University of Vermont Main Campus greenhouse facility from April 4 to May 8, 2019 ( $n=96$ seeds per plant-amendment-application rate combination). Greenhouse temperature set points were $20{ }^{\circ} \mathrm{C}$ (heating) and $24{ }^{\circ} \mathrm{C}$ (ventilation) with supplemental high-intensity discharge lighting provided during the day. Cells were misted up to twice per day with tap water to ensure adequate moisture.

The number of germinated seedlings in each tray was recorded daily and used to calculate percent germination ( $n=6$ trays per plant-amendment-application rate combination). Not all seeds that germinated survived to become viable seedlings. Seedlings were considered viable at the time of harvest if they had at least one set of true leaves and were not visibly exhibiting indications of disease (e.g., standing upright, no tissue decay at or below soil surface). Percent seedling survival was calculated by subtracting numbers of viable seedlings in a tray from the total number of seeds that germinated and dividing by the total number of seeds that germinated ( $n=6$ trays per plant-amendment-application rate combination).

Four seedlings from each tray were selected randomly from the subset of seedlings that met the harvest criteria and destructively harvested after 4 weeks $(n=24$ seedlings per plantamendment-application rate combination). Roots and shoots were separated and dried in an oven at approximately $57^{\circ} \mathrm{C}$ for at least $48 \mathrm{~h}$ before being weighed for dry biomass. Total biomass for each seedling was calculated by summing root and shoot dry biomass.

Germination, seedling survival, root, shoot and total dry biomass were compared across all amendment-application rate combinations for each plant by a one-way Kruskal-Wallis test followed by a Dunn-Bonferroni post-hoc comparison $(\alpha=0.05)$. Statistical analyses were performed with RStudio Version 1.1.383.

\subsection{Pathogen Suppression Assay}

A plate competition assay method [31] was used to examine suppression of $R$. solani, one of the most important pathogens on crop plants [32]. The method compares the ability of $R$. solani to grow with and without living microbes in the media of interest. Briefly, $0.5 \mathrm{~g}$ of as-is fine solids or the market alternative was added to a pair of flasks with $50 \mathrm{~mL}$ of sterile water and shaken overnight. The following day, two flasks were prepared with $1.5 \mathrm{~g}$ agar added to $50 \mathrm{~mL}$ deionized water, autoclaved for $30 \mathrm{~min}$, then cooled to $55^{\circ} \mathrm{C}$. One of the two subsamples was added to the water agar before autoclaving (to kill microbes) and the second after autoclaving (living microbes). Each flask was swirled gently to mix and poured into five $100 \mathrm{~mm} \times 15 \mathrm{~mm}$ plastic petri plates. After $24 \mathrm{~h}$, plugs of $R$. solani growing on potato dextrose agar were transferred onto the surface of the solidified water agar mixtures. Plates were incubated for $24 \mathrm{~h}$ at room temperature after which mycelium radii were measured to the nearest $1 \mathrm{~mm}$ using a microscope. The three longest radii were recorded for each plate. Suppressive potential was computed as the difference of mycelial radii of the non-autoclaved subsample from the autoclaved subsample (control). Negative values represented suppressive potential. 


\subsection{Materials Characterization}

Representative samples of as-is fine solids, partially dried fine solids, other blend ingredients, derived plant foods, and the market alternative were sent to a commercial laboratory (University of Maine Analytical Lab, Orono, ME) for standard soil amendment testing for bulk density, $\mathrm{pH}$, conductivity, total solids, total volatile solids, total $\mathrm{C}$, total $\mathrm{N}, \mathrm{NH}_{4}-\mathrm{N}, \mathrm{NO}_{3}-\mathrm{N}, \mathrm{B}, \mathrm{Ca}, \mathrm{Cu}, \mathrm{Fe}, \mathrm{K}, \mathrm{Mg}$, $\mathrm{Mn}, \mathrm{Na}, \mathrm{P}$, and $\mathrm{Zn}$. Bulk density was determined by dividing the mass of material filling a $430 \mathrm{~cm}^{3}$ container by its volume. Soil $\mathrm{pH}$ was measured from a saturation paste using a Corning $220 \mathrm{pH}$ meter with an Accumet probe and conductivity was measured on the filtrate [33]. Total solids were determined by weighing samples before and after oven drying for $12 \mathrm{~h}$ at $110^{\circ} \mathrm{C}$. Separate sub-samples were combusted for $6 \mathrm{~h}$ at $550^{\circ} \mathrm{C}$ to determine total volatile solids as mass loss on ignition. Total C was determined by dry combustion and analysis using a Leco TruMac, as was total $\mathrm{N}$ for the market alternative, soilless substrate, dried distiller's grain and whey permeate formulation, and biochar. Total $\mathrm{N}$ was estimated as total Kjeldahl $\mathrm{N}+\mathrm{NO}_{3}-\mathrm{N}$ for as-is fine solids, partially dried fine solids, and all plant foods. Total Kjeldahl $\mathrm{N}$ was determined as described by Combs et al. [34]. $\mathrm{NH}_{4}-\mathrm{N}$ and $\mathrm{NO}_{3}-\mathrm{N}$ were determined by extracting $5 \mathrm{~g}$ dried and sieved $(<2 \mathrm{~mm}$ ) sample in $50 \mathrm{~mL}$ of $1 \mathrm{M} \mathrm{KCl}$ (1:10 solids:solution ratio) followed by colorimetric analysis of extracts with an O.I. Alpkem A/E ion analyzer. For all other nutrients, $5 \mathrm{~g}$ of dried and ground sample were combusted at $550{ }^{\circ} \mathrm{C}$ for $6 \mathrm{~h}$ and then extracted with $50 \% \mathrm{HCl}$ solution. Extracts were measured by ICP-AES for $\mathrm{B}, \mathrm{Ca}, \mathrm{Cu}, \mathrm{Fe}$, $\mathrm{K}, \mathrm{Mg}, \mathrm{Mn}, \mathrm{Na}, \mathrm{P}$ and $\mathrm{Zn}$ in accordance with EPA method 200.7. Additionally, fertilizer-available P and soluble $\mathrm{K}$ were determined by extraction with a neutral $\mathrm{NH}_{4}$ citrate-disodium EDTA solution in accordance with AOAC method 993.01.

A detailed assessment of $P$ forms in the fine solids and derived plant foods was conducted the University of Vermont. Extractions were performed on as-is and partially dried fine solids, derived plant foods, and the market alternative to determine water extractable $\mathrm{P}, 2 \%$ citric acid extractable $\mathrm{P}$, and Olsen P. These three metrics collectively indicate P solubility in soils over shorter and longer time scales across a range of soil $\mathrm{pH}$ levels [35]. Samples were extracted with deionized water and $2 \%$ citric acid $\left(\mathrm{C}_{6} \mathrm{H}_{8} \mathrm{O}_{7}\right)$ at a 2:200 solids: solution ratio to determine water extractable $\mathrm{P}$ and $2 \%$ citric acid extractable $\mathrm{P}$, respectively. Olsen $\mathrm{P}$ was determined by equilibrating samples in a 2:40 solids: solution ratio with $0.5 \mathrm{M}$ sodium bicarbonate $\left(0.5 \mathrm{M} \mathrm{NaHCO}_{3}\right.$ adjusted to $\mathrm{pH} 8.5$ with $\left.1 \mathrm{M} \mathrm{NaOH}\right)$. Water extractable P suspensions were shaken for $60 \mathrm{~min}$ and $2 \%$ citric acid and Olsen P suspensions were both shaken for $30 \mathrm{~min}$ and then centrifuged at 4066 times $g$ for $10 \mathrm{~min}$. The supernatants were passed through a $0.45 \mu \mathrm{m}$ filter and then stored in a freezer prior to analysis. Water extractable, $2 \%$ citric acid and Olsen P extracts were diluted 1:100, 1:200 and 1:300, respectively, with deionized water and then analyzed for soluble reactive P using the colorimetric malachite green method [36].

\section{Results and Discussion}

\subsection{Physicochemical Characteristics}

The total solids content of the plant foods ranged from $47.0-50.9 \%$ and the volatile solids content ranged from $36.4-40.3 \%$ (Table 2). Despite a nearly three-fold increase in total solids content during partial drying and blending, plant foods had approximately half the total solids content of the market alternative (Table 2). Though the partially dried fine solids had a $\mathrm{pH}$ of 8.4, the $\mathrm{pH}$ of plant foods ranged from 7.7-7.9 (Table 2). This reduction in $\mathrm{pH}$ may be a result of blending with the dried distiller's grain and whey permeate formulation, which had a $\mathrm{pH}$ of 4.6 (Table 2). 
Table 2. Physicochemical characteristics of as-is and dried fine solids, other blend ingredients, derived plant foods, and the market alternative on an as-is basis.

\begin{tabular}{|c|c|c|c|c|c|c|c|c|c|c|}
\hline & $\begin{array}{l}\text { As-is } \\
\text { Fine } \\
\text { Solids }\end{array}$ & $\begin{array}{l}\text { Dried } \\
\text { Fine } \\
\text { Solids }\end{array}$ & $\begin{array}{l}\text { Soilless } \\
\text { Substrate }\end{array}$ & $\begin{array}{c}\text { Dried } \\
\text { Distiller's } \\
\text { Grain \& Whey } \\
\text { Permeate }\end{array}$ & Biochar & $\begin{array}{c}\text { Plant } \\
\text { Food } \\
\text { A }\end{array}$ & $\begin{array}{c}\text { Plant } \\
\text { Food } \\
\mathbf{A}_{1}\end{array}$ & $\begin{array}{c}\text { Plant } \\
\text { Food } \\
\mathbf{A}_{2}\end{array}$ & $\begin{array}{c}\text { Plant } \\
\text { Food } \\
\text { B }\end{array}$ & $\begin{array}{c}\text { Market } \\
\text { Alternative }\end{array}$ \\
\hline Volatile Solids (\%) & 12.8 & 34.2 & 45.5 & 88.6 & 44.8 & 36.4 & 38.4 & 40.3 & 37.8 & NA \\
\hline $\mathrm{pH}$ & 8.0 & 8.4 & 6.4 & 4.6 & 9.5 & 7.8 & 7.7 & 7.7 & 7.9 & NA \\
\hline $\begin{array}{l}\text { Bulk density } \\
\left(\mathrm{kg} \mathrm{m}^{-3}\right)\end{array}$ & 1006 & 415 & 136 & 570 & 356 & 463 & 534 & 445 & 457 & NA \\
\hline $\mathrm{C}: \mathrm{N}$ ratio & 8.1 & 19.6 & 57.7 & 11.8 & 30.9 & 9.3 & 9.9 & 10.5 & 9.7 & NA \\
\hline $\begin{array}{l}\text { Total C } \\
\left(\mathrm{g} \mathrm{kg}^{-1}\right)\end{array}$ & 69 & 174 & 227 & 434 & 354 & 181 & 204 & 216 & 189 & NA \\
\hline
\end{tabular}

${ }^{a}$ Measured at the University of Vermont by oven drying for $24 \mathrm{~h}$ at $60^{\circ} \mathrm{C}$.

\subsection{Nitrogen}

Partially drying fine solids slightly increased total $\mathrm{N}$ content (\%) on an as-is basis (Table 3) despite substantial $\mathrm{N}$ mass loss during drying (Table S1 (see supplementary)). On a dry basis, total N content decreased by $61 \%$ during drying (Table S1), likely due to volatilization of ammonia $\left(\mathrm{NH}_{4}{ }^{+}\right.$to $\left.\mathrm{NH}_{3}\right)$. This is evidenced by the $84 \%$ reduction in $\mathrm{NH}_{4}-\mathrm{N}$ content following partial drying (Table S1). The total quantity of $\mathrm{N}$ lost and the $54 \%$ reduction in the organic $\mathrm{N}$ pool during drying both indicate that coupled mineralization-volatilization (organic $\mathrm{N}$ to $\mathrm{NH}_{4}{ }^{+}$to $\mathrm{NH}_{3}$ ) occurred as well (Table S1). The $\mathrm{N}$ loss observed is consistent with a previous study of separated digestate solids, which reported an $80 \%$ reduction in $\mathrm{NH}_{4}-\mathrm{N}$ during drying [37]. Despite some loss of volatile $\mathrm{N}$ species, the total $\mathrm{N}$ content of the fine solids was not substantially altered by partial drying on an as-is basis (Table 3) due to the nearly three-fold increase in total solids content (Table 2), which concentrated the remaining $\mathrm{N}$.

The plant foods had about twice the total $\mathrm{N}$ content of the partially dried fine solids (Table 3), which indicates that the dried distiller's grain and whey permeate formulation and biochar contributed substantial $\mathrm{N}$ to the blends. Plant foods had a total $\mathrm{N}$ content comparable to the market alternative on a dry basis (Table S1) but contained approximately 50\% less total $\mathrm{N}$ than the market alternative on an as-is basis (Table 3). Relatively lower $\mathrm{N}$ is typical of organic fertilizers, which are often far more dilute than commercial fertilizers due to higher moisture content [38]. $\mathrm{NH}_{4}-\mathrm{N}+\mathrm{NO}_{3}-\mathrm{N}$ ranged from $2-4 \%$ of total $\mathrm{N}$ in plant foods (Table 3), which indicates that only a small fraction of $\mathrm{N}$ present in fine solids and derived plant foods is immediately available for plant uptake or susceptible to loss via leaching. However, plant food C:N ratio ranged from 9.3 to 10.5 (Table 2), indicating potential for organic $\mathrm{N}$ to become plant available over time via ammonification [39]. 
Table 3. Nitrogen $(\mathrm{N})$, phosphorus $(\mathrm{P})$ and potassium $(\mathrm{K})$ content of as-is and dried fine solids, other blend ingredients, derived plant foods, and the market alternative on an as-is basis.

\begin{tabular}{|c|c|c|c|c|c|c|c|c|c|c|}
\hline & $\begin{array}{l}\text { As-is } \\
\text { Fine } \\
\text { Solids }\end{array}$ & $\begin{array}{l}\text { Dried } \\
\text { Fine } \\
\text { Solids }\end{array}$ & $\begin{array}{l}\text { Soilless } \\
\text { Substrate }\end{array}$ & $\begin{array}{c}\text { Dried } \\
\text { Distiller's } \\
\text { Grain \& } \\
\text { Whey } \\
\text { Permeate }\end{array}$ & Biochar & $\begin{array}{l}\text { Plant } \\
\text { Food } \\
\text { A }\end{array}$ & $\begin{array}{l}\text { Plant } \\
\text { Food } \\
\text { A }_{1}\end{array}$ & $\begin{array}{l}\text { Plant } \\
\text { Food } \\
\mathbf{A}_{2}\end{array}$ & $\begin{array}{l}\text { Plant } \\
\text { Food } \\
\text { B }\end{array}$ & $\begin{array}{c}\text { Market } \\
\text { Alternative }\end{array}$ \\
\hline $\begin{array}{l}\text { Total N } \\
\left(\mathrm{g} \mathrm{kg}^{-1}\right)\end{array}$ & $8.5^{\mathrm{a}}$ & $8.9^{\mathrm{a}}$ & $3.9^{\mathrm{b}}$ & $36.8^{\mathrm{b}}$ & $11.5^{\mathrm{b}}$ & $19.6^{\mathrm{a}}$ & $\begin{array}{c}20.6 \\
a\end{array}$ & $\begin{array}{c}20.6 \\
a\end{array}$ & $19.6^{\mathrm{a}}$ & $41.7^{b}$ \\
\hline $\begin{array}{l}\text { Organic N } \\
\left(\mathrm{g} \mathrm{kg}^{-1}\right)\end{array}$ & $6.6^{c}$ & $8.0^{\mathrm{c}}$ & $3.9^{\mathrm{d}}$ & $36.6^{\mathrm{d}}$ & $11.3^{\mathrm{d}}$ & $18.8^{\mathrm{c}}$ & $20.1^{c}$ & $20.2^{c}$ & $18.9^{\mathrm{c}}$ & NA \\
\hline $\begin{array}{l}\text { NH4-N } \\
\left(\mathrm{g} \mathrm{kg}^{-1}\right)\end{array}$ & 1.92 & 0.82 & 0.03 & 0.09 & 0.21 & 0.72 & 0.54 & 0.37 & 0.64 & NA \\
\hline $\begin{array}{l}\text { NO3-N } \\
\left(\mathrm{g} \mathrm{kg}^{-1}\right)\end{array}$ & 0.00 & 0.00 & 0.00 & 0.00 & 0.00 & 0.00 & 0.00 & 0.00 & 0.00 & NA \\
\hline $\begin{array}{l}\text { Total P } \\
\left(\mathrm{g} \mathrm{kg}^{-1}\right)\end{array}$ & 3.1 & 7.8 & 0.4 & 4.9 & 5.3 & 7.6 & 8.5 & 8.9 & 7.8 & 17.9 \\
\hline $\begin{array}{l}\text { Neutral NH4 } \\
\text { Citrate P } \\
\left(\mathrm{g} \mathrm{kg}^{-1}\right)\end{array}$ & 3.3 & 8.9 & 0.3 & 4.9 & 4.4 & 8.1 & 8.2 & 8.1 & 8.2 & 14.6 \\
\hline $\begin{array}{l}2 \% \text { Citric Acid P } \\
\left(\mathrm{g} \mathrm{kg}^{-1}\right)\end{array}$ & 2.5 & 5.7 & NA & NA & NA & 6.0 & 5.8 & 5.4 & 6.2 & 9.2 \\
\hline $\begin{array}{l}\text { Olsen P } \\
\left(\mathrm{g} \mathrm{kg}^{-1}\right)\end{array}$ & 0.1 & 0.9 & NA & NA & NA & 1.0 & 1.0 & 1.2 & 0.8 & 0.7 \\
\hline $\begin{array}{l}\text { Water } \\
\text { Extractable P } \\
\left(\mathrm{g} \mathrm{kg}^{-1}\right)\end{array}$ & 0.3 & 1.4 & NA & NA & NA & 1.6 & 1.8 & 1.9 & 1.9 & 2.1 \\
\hline $\begin{array}{l}\text { Total K } \\
\left(\mathrm{g} \mathrm{kg}^{-1}\right) \\
\text { Neutral NH4 }\end{array}$ & 2.5 & 5.9 & 0.8 & 7.0 & 20.0 & 6.3 & 7.2 & 7.6 & 6.8 & 18.1 \\
\hline $\begin{array}{l}\text { Citrate K } \\
\left(\mathrm{g} \mathrm{kg}^{-1}\right)\end{array}$ & 3.1 & 7.7 & 1.0 & 7.8 & 20.9 & 7.9 & 8.0 & 8.0 & 7.9 & 19.9 \\
\hline
\end{tabular}

${ }^{a}$ Total $\mathrm{N}$ calculated as sum of total Kjeldahl $\mathrm{N}$ and $\mathrm{NO}_{3}-\mathrm{N} ;{ }^{\mathrm{b}}$ Total $\mathrm{N}$ measured by combustion analysis; ${ }^{\mathrm{c}}$ Organic $\mathrm{N}$ is estimated as total Kjeldahl $\mathrm{N}-\mathrm{NH}_{4}-\mathrm{N} ;{ }^{\mathrm{d}}$ Organic $\mathrm{N}$ estimated as total $\mathrm{N}-\left(\mathrm{NH}_{4}-\mathrm{N}+\mathrm{NO}_{3}-\mathrm{N}\right)$.

\subsection{Phosphorus}

Partially drying fine solids increased total P content two-fold on an as-is basis (Table 3 ) and did not substantially alter P content on a dry weight basis (Table S1). Water extractable P increased from 10 to $18 \%$ of total $\mathrm{P}$ during partial drying (Table 3). This is consistent with prior reports that thermal drying increased the water extractable $P$ fraction in digestate solids [37] — potentially by liberating $P$ bound in microbial cellular structures or through desorption of $P$ from the surfaces of colloids [40]. Water extractable P ranged from $20-22 \%$ of total $\mathrm{P}$ in plant foods (Table 3 ). We found that $2 \%$ citric acid extraction liberated $61-79 \%$ of the total $\mathrm{P}$ contained in plant foods, and neutral $\mathrm{NH}_{4}$ citrate extraction liberated nearly all $\mathrm{P}$ in fine solids and derived plant foods (Table 3). This indicates that fine solids and derived plant foods contain a mixture of immediately plant-available $\mathrm{P}$ and $\mathrm{P}$ bound in other forms that likely become plant-available over time [35], potentially providing slow release fertilization to growing seedlings.

\subsection{Other Nutrients}

Partially drying fine solids increased total K content two-fold on an as-is basis (Table 3) and did not substantially alter $\mathrm{K}$ content on a dry weight basis (Table S1). Plant foods contained $58-65 \%$ less total $\mathrm{K}$ than the market alternative on an as-is basis (Table 3). The majority of total $\mathrm{K}$ was soluble in all materials tested (Table 3). Plant foods also contained detectable levels of the macronutrients $\mathrm{Ca}$ and $\mathrm{Mg}$ as well as the micronutrients $\mathrm{B}, \mathrm{Cu}, \mathrm{Fe}, \mathrm{Mn}, \mathrm{Na}$, and $\mathrm{Zn}$ (Table 4) -all of which are considered essential to plant function [41]. Plant foods had higher levels than the market alternative of the nutrients $\mathrm{B}, \mathrm{Cu}$, $\mathrm{Fe}, \mathrm{Mg}, \mathrm{Mn}$ and $\mathrm{Na}$ and lower levels of $\mathrm{Ca}$ and $\mathrm{Zn}$ (Table 4). 
Table 4. Other nutrient contents of as-is and dried fine solids, other blend ingredients, derived plant foods, and the market alternative on an as-is basis.

\begin{tabular}{|c|c|c|c|c|c|c|c|c|c|c|}
\hline & $\begin{array}{l}\text { As-is } \\
\text { Fine } \\
\text { Solids }\end{array}$ & $\begin{array}{l}\text { Dried } \\
\text { Fine } \\
\text { Solids }\end{array}$ & $\begin{array}{l}\text { Soilless } \\
\text { Substrate }\end{array}$ & $\begin{array}{c}\text { Dried } \\
\text { Distiller's } \\
\text { Grain \& Whey } \\
\text { Permeate }\end{array}$ & Biochar & $\begin{array}{l}\text { Plant } \\
\text { Food } \\
\text { A }\end{array}$ & $\begin{array}{c}\text { Plant } \\
\text { Food } \\
\mathbf{A}_{1}\end{array}$ & $\begin{array}{c}\text { Plant } \\
\text { Food } \\
\mathrm{A}_{2}\end{array}$ & $\begin{array}{c}\text { Plant } \\
\text { Food } \\
\text { B }\end{array}$ & $\begin{array}{c}\text { Market } \\
\text { Alternative }\end{array}$ \\
\hline $\begin{array}{l}\text { Total B } \\
\left(\mathrm{g} \mathrm{kg}^{-1}\right)\end{array}$ & 0.00 & 0.01 & 0.02 & 0.00 & 0.02 & 0.01 & 0.01 & 0.01 & 0.01 & 0.00 \\
\hline $\begin{array}{l}\text { Total Ca } \\
\left(\mathrm{g} \mathrm{kg}^{-1}\right)\end{array}$ & 5.5 & 15 & 17 & 2 & 22 & 10 & 11 & 11 & 11 & 52 \\
\hline $\begin{array}{l}\text { Total Cu } \\
\left(\mathrm{g} \mathrm{kg}^{-1}\right)\end{array}$ & 0.11 & 0.30 & 0.03 & 0.00 & 0.02 & 0.31 & 0.35 & 0.35 & 0.33 & 0.03 \\
\hline $\begin{array}{l}\text { Total Fe } \\
\left(\mathrm{g} \mathrm{kg}^{-1}\right)\end{array}$ & 0.14 & 0.38 & 1.28 & 0.20 & 1.61 & 0.38 & 0.39 & 0.40 & 0.39 & 0.24 \\
\hline $\begin{array}{l}\text { Total Mg } \\
\left(\mathrm{g} \mathrm{kg}^{-1}\right)\end{array}$ & 2.0 & 5.6 & 3.5 & 1.4 & 9.6 & 5.6 & 6.3 & 6.0 & 5.9 & 3.2 \\
\hline $\begin{array}{l}\text { Total Mn } \\
\left(\mathrm{g} \mathrm{kg}^{-1}\right)\end{array}$ & 0.04 & 0.10 & 0.07 & 0.01 & 0.18 & 0.11 & 0.12 & 0.12 & 0.12 & 0.07 \\
\hline $\begin{array}{l}\text { Total Na } \\
\left(\mathrm{g} \mathrm{kg}^{-1}\right)\end{array}$ & 1.0 & 2.5 & 0.2 & 1.6 & 4.6 & 2.4 & 2.8 & 2.6 & 2.6 & 1.6 \\
\hline $\begin{array}{l}\text { Total Zn } \\
\left(\mathrm{g} \mathrm{kg}^{-1}\right)\end{array}$ & 0.06 & 0.16 & 0.06 & 0.05 & 0.09 & 0.14 & 0.16 & 0.16 & 0.15 & 0.26 \\
\hline
\end{tabular}

\subsection{Germination}

Plant foods did not inhibit germination at any application rate tested. Tomato germination rate was not significantly different from the control for any application rate of Plant Food B or the market alternative, however the $8 \% v / v$ and $10 \% v / v$ Plant Food B groups had significantly higher germination rates than the market alternative group (Figure 3). Marigold germination was unaffected by the amendment or application rate; however, those grown in the market alternative had the lowest mean germination rate (Figure 3). Surface caking was not observed in this study, which suggests that partially drying fine solids prior to blending the plant foods addressed the texture issues experienced with the as-is plant foods in preliminary experimentation.

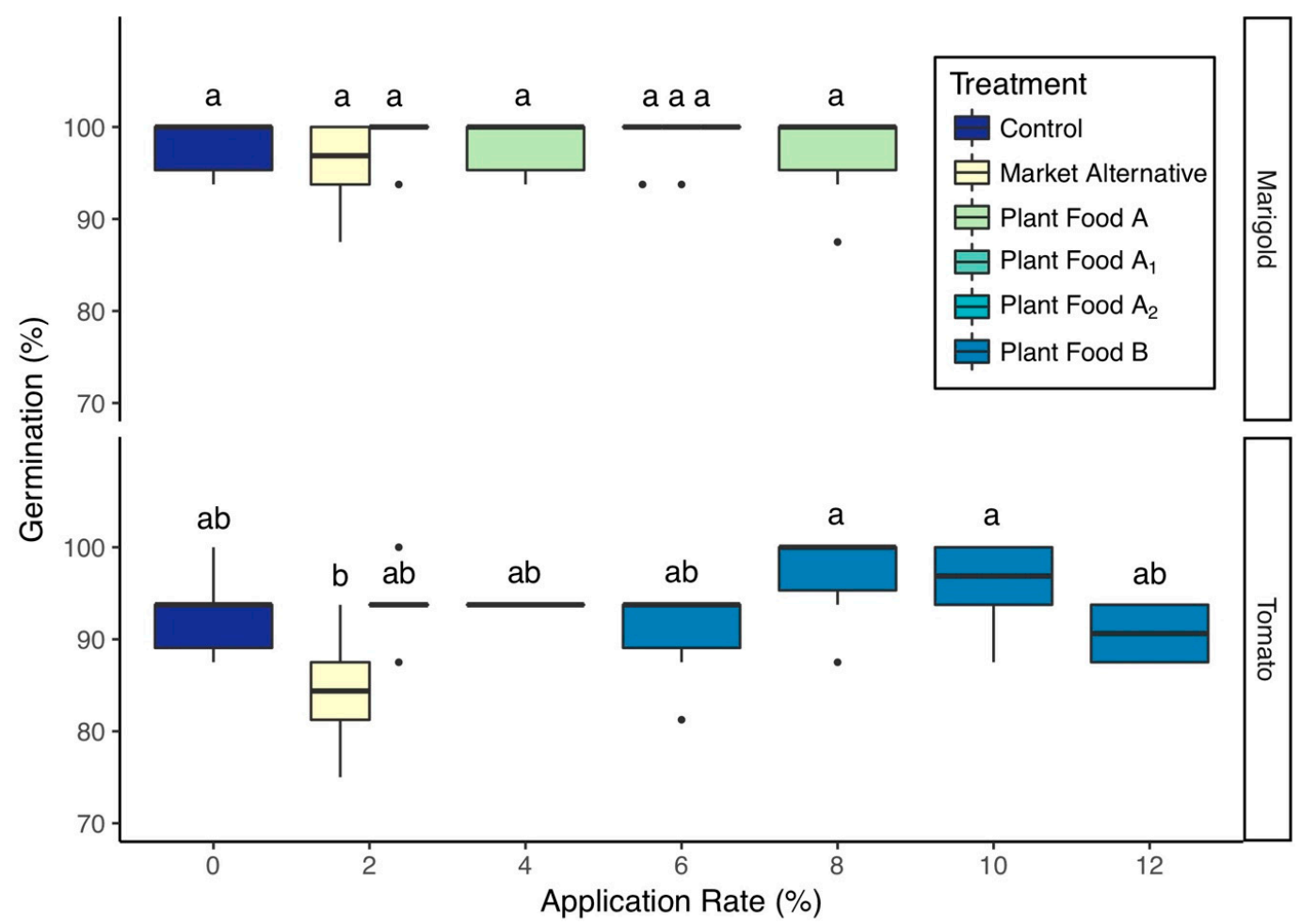

Figure 3. Seedling germination by amendment and application rate (mean $\pm 1 \mathrm{SD})$. Groups share a letter if the difference in means was not statistically significant $(P>0.05)$. 
Seedling survival was not significantly different from the control group for any application rate of either plant food tested, with the exception of marigolds grown in $8 \% v / v$ Plant Food A, which had a lower survival rate than the control and $2 \% v / v$ Plant Food A groups $(P=0.04 \& P=0.04$, Table S2 (see supplementary)).

\subsection{Biomass}

Tomatoes amended with Plant Food B had greater total biomass than the control at $4-12 \% v / v$ and comparable biomass to the market alternative group at 6-12\% $v / v$ (Figure 4 ). This is likely because $6 \%$ $v / v$ is the application rate at which the N, P and K addition rate met or exceeded the rate supplied by the market alternative treatment (Figure 5). Of the plant food recipes and application rates tested for tomatoes, the greatest mean biomass was produced by the $6 \%$ Plant Food B group, after which there were diminishing returns in biomass with increased application rate (Figure 4).

Marigolds amended with Plant Food A had greater total biomass than the control group and comparable biomass to the market alternative group at 4-8\% $v / v$ (Figure 4). Marigolds amended with $6 \% v / v$ of two modified Plant Food A recipes (Plant Food $\mathrm{A}_{1}$ and Plant Food $\mathrm{A}_{2}$ ) also had greater total biomass than the control group and were not significantly different from the market alternative group (Figure 4). Of the plant food recipes and application rates tested for marigolds, the greatest biomass was produced by the $6 \% v / v$ Plant Food $\mathrm{A}_{2}$ group, which contained the highest proportion of dried distiller's grain and whey permeate formulation (Figure 4 and Table 1 ). The mean biomass of this group was significantly greater than that of the $6 \% v / v$ Plant Food A group, though not significantly different from the $4 \%$ or $8 \% v / v$ Plant Food A groups (Figure 4). This suggests that plant foods with a higher proportion of dried distiller's grain and whey permeate formulation may be more suitable for flower production; however, further investigation is needed to confirm this observation and elucidate the mechanism behind the trend. The increased proportion of dried distiller's grain and whey permeate formulation in Plant Food $\mathrm{A}_{1}$ and $\mathrm{A}_{2}$ only modestly increased N, P and K content (Table 3), and nutrient addition rates (Figure 5), which suggests that some other factor may have contributed to the observed increase in biomass in the Plant Food $\mathrm{A}_{2}$ group. For both tomatoes and marigolds, differences in root and shoot biomass followed similar patterns as total biomass (Table S2).

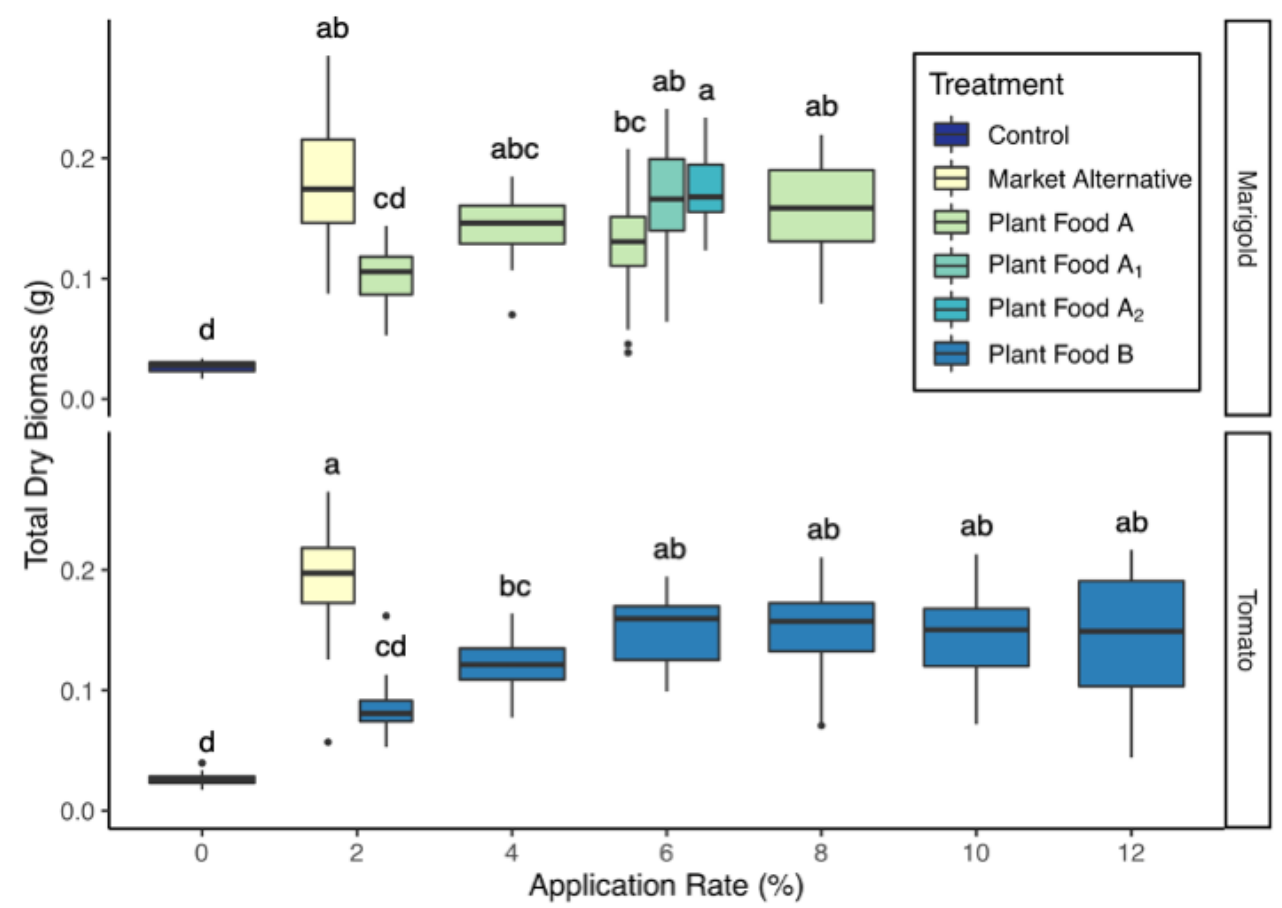

Figure 4. Seedling dry biomass by amendment and application rate (mean $\pm 1 \mathrm{SD})$. Groups share a letter if the difference in means was not statistically significant $(P>0.05)$. 


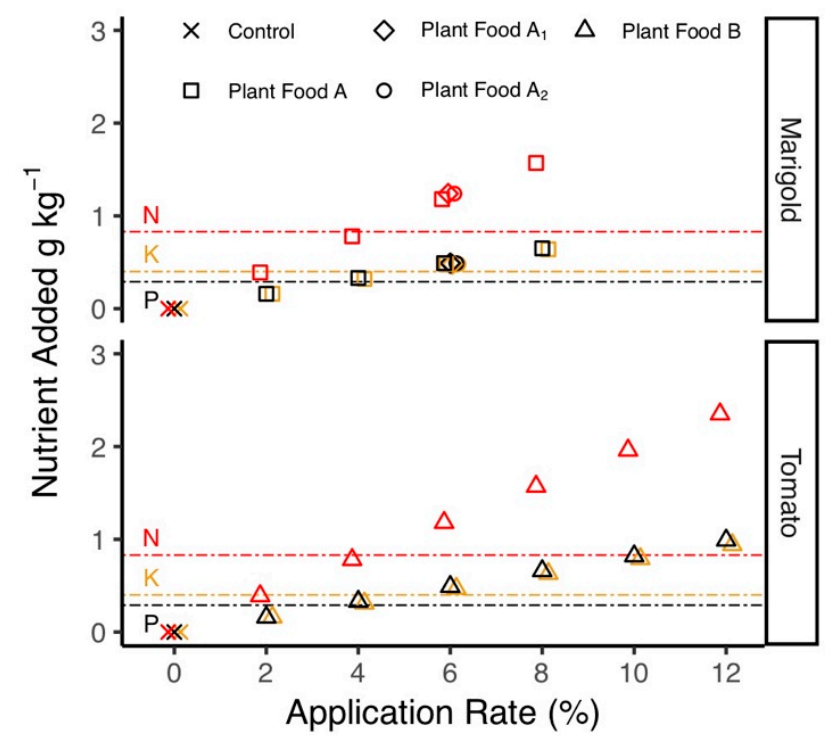

Figure 5. Nutrient additions ( $\mathrm{g}$ nutrient added per $\mathrm{kg}$ total substrate blend) for seedlings by amendment and application rate. Dashed lines represent nutrient additions from the market alternative at $2 \%$ v/v. $\mathrm{N}=$ total $\mathrm{N}, \mathrm{P}=\mathrm{P}$ extracted by neutral ammonium citrate, and $\mathrm{K}=\mathrm{K}$ extracted by neutral ammonium citrate.

\subsection{Pathogen Suppression}

As-is fine solids exhibited negligible potential to suppress R. solani, as did the market alternative (Figure S1 (see supplementary)). Neither amendment exhibited evidence of accelerating $R$. solani growth. A previous study found that coarse solids separated from dairy manure digestate via screw-press do have substantial potential to suppress $R$. solani [20], which suggests that differences in physicochemical properties between coarse and fine separated solids may influence suppressive potential.

\subsection{Future Work}

Plant foods made from DAF-captured fine solids provided fertilization for tomatoes and marigolds without inhibiting germination, indicating potential market value as bagged products (e.g., $<10 \mathrm{~kg}$ ) for horticultural seedling production. A remaining barrier to bringing these plant foods to market is finding a sustainable and cost-effective way to dry DAF-captured fine solids on a larger scale. Drying cost and energy intensity depend on the method employed, evaluation of which is beyond the scope of this study. Others have shown that a hybrid waste heat/solar drier achieved substantial moisture reduction of pre-screw press digestate using a combination of solar heat and waste heat captured from biogas production [42]. Further work is needed to identify the most sustainable and cost-effective drying option for DAF-captured dairy manure fine solids in Vermont and elsewhere, and to further elucidate the optimal ratios of plant food components for other types of horticulture production. Based on past experience selling bagged products made using coarse digestate solids (i.e., Magic $\operatorname{Dirt}^{\mathrm{TM}}$ ), we expect that all economic costs for bringing a bagged product including DAF-captured fine solids to market will vary region to region. Ingredient costs will include the DAF-captured fine solids and the other blend ingredients (e.g., dried distiller's grains and dried whey permeate, biochar). Other costs, including bags and bagging, transportation, marketing, and corporate overhead, will collectively be much greater than the total ingredient cost and will therefore factor prominently in product pricing. Detailed investigation of the wider economic and environmental life cycle aspects of this nutrient recovery strategy is a necessary next step to further guide sustainability efforts. 


\section{Conclusions}

In this study, we found that fine solids recovered from digested dairy manure via DAF can be upcycled into products with substantial fertilization value for horticultural applications (e.g., vegetables and flowers). Plant foods had no negative effects on tomato or marigold germination rate at any application rate tested and increased total seedling biomass six-fold compared to the control at $6 \%$ $v / v$. This strong agronomic potential for horticultural applications may create opportunities to export surplus $\mathrm{P}$ to the marketplace as a bagged plant food product, aiding efforts to better balance $\mathrm{P}$ budgets on dairy farms.

Supplementary Materials: The following are available online at http:/www.mdpi.com/2071-1050/12/3/1139/s1, Table S1: Nutrient contents of materials on a dry weight basis, Table S2: Bioassay germination rates, survival rates, root dry biomass, shoot dry biomass and total dry biomass by amendment and application rate, Figure S1: Pathogen suppression potential of as-is fine solids and the market alternative

Author Contributions: Conceptualization, R.J., D.A.N., M.C., S.D., D.M.R., J.W.F. and E.D.R.; Formal analysis, K.K.P. and D.A.N.; Funding acquisition, M.C., S.D., D.M.R., J.W.F. and E.D.R.; Investigation, K.K.P. and D.A.N.; Methodology, K.K.P., R.J., D.A.N. and E.D.R.; Project administration, M.C., S.D. and E.D.R.; Resources, R.J. and S.D.; Supervision, E.D.R.; Validation, K.K.P., D.A.N. and E.D.R.; Visualization, K.K.P.; Writing-Original draft, K.K.P. and E.D.R.; Writing-Review \& editing, K.K.P., R.J., D.A.N., M.C., S.D., D.M.R., J.W.F. and E.D.R. All authors have read and agreed to the published version of the manuscript.

Funding: This work was funded by the State of Vermont's Phosphorus Innovation Challenge (Grant \#: 02200-WQ-VPIC-2019-003).

Acknowledgments: We acknowledge Tom Weicht, Adrian Weigman, Mike Ament, Marcos Kubow, Michaela Morgan, Nisha Nadkarni, Marcus Shapiro, Sadie Shelton and Mike Sztorc for their help with data collection and analysis. We also thank the University of Vermont greenhouse team for helping to water the seedlings.

Conflicts of Interest: Co-authors R.J., M.C., and S.D. are employed by for-profit corporations working in the areas of anaerobic digestion technology and digestate-based horticultural products. To mitigate potential competing interests, these co-authors were not involved in investigation, data validation, formal analysis, or visualization of data in this study.

\section{References}

1. Cordell, D.; Drangert, J.-O.; White, S. The story of phosphorus: Global food security and food for thought. Glob. Environ. Chang. 2009, 19, 292-305. [CrossRef]

2. Wironen, M.B.; Bennett, E.M.; Erickson, J.D. Phosphorus flows and legacy accumulation in an animal-dominated agricultural region from 1925 to 2012. Glob. Environ. Chang. 2018, 50, 88-99. [CrossRef]

3. Childers, D.L.; Corman, J.; Edwards, M.; Elser, J.J. Sustainability challenges of phosphorus and food: Solutions from closing the human phosphorus cycle. Biosci. Oxf. 2011, 61, 117-124. [CrossRef]

4. Riding, M.J.; Herbert, B.M.J.; Ricketts, L.; Dodd, I.; Ostle, N.; Semple, K.T. Harmonising conflicts between science, regulation, perception and environmental impact: The case of soil conditioners from bioenergy. Environ. Int. 2015, 75, 52-67. [CrossRef] [PubMed]

5. Roy, E.D. Phosphorus recovery and recycling with ecological engineering: A review. Ecol. Eng. 2017, 98, 213-227. [CrossRef]

6. Sarvajayakesavalu, S.; Lu, Y.; Withers, P.J.A.; Pavinato, P.S.; Pan, G.; Chareonsudjai, P. Phosphorus recovery: A need for an integrated approach. Ecosyst. Health Sustain. 2018, 4, 48-57. [CrossRef]

7. Powers, S.M.; Chowdhury, R.B.; MacDonald, G.K.; Metson, G.S.; Beusen, A.H.W.; Bouwman, A.F.; Hampton, S.E.; Mayer, B.K.; McCrackin, M.L.; Vaccari, D.A. Global opportunities to increase agricultural independence through phosphorus recycling. Earths Future 2019, 7, 370-383. [CrossRef]

8. Vermont Office of the Governor. Vermont Phosphorus Innovation Challenge; Brief from the Vermont Office of the Governor: Montpelier, VT, USA, 2018.

9. USEPA AgSTAR Data and Trends. Available online: https://www.epa.gov/agstar/agstar-data-and-trends (accessed on 3 June 2019).

10. Lukehurst, C.T.; Frost, P.; Seadi, T.A. Utilisation of digestate from biogas plants as biofertiliser. IEA Bioenergy 2010, 2010, 1-36. 
11. Campos, J.L.; Crutchik, D.; Franchi, Ó.; Pavissich, J.P.; Belmonte, M.; Pedrouso, A.; Mosquera-Corral, A.; Val del Río, Á. Nitrogen and phosphorus recovery from anaerobically pretreated agro-food wastes: A review. Front. Sustain. Food Syst. 2019, 2, 91. [CrossRef]

12. Tambone, F.; Orzi, V.; D’Imporzano, G.; Adani, F. Solid and liquid fractionation of digestate: Mass balance, chemical characterization, and agronomic and environmental value. Bioresour. Technol. 2017, 243, 1251-1256. [CrossRef]

13. Pizzeghello, D.; Berti, A.; Nardi, S.; Morari, F. Phosphorus forms and P-sorption properties in three alkaline soils after long-term mineral and manure applications in north-eastern Italy. Agric. Ecosyst. Environ. 2011, 141, 58-66. [CrossRef]

14. Pizzeghello, D.; Berti, A.; Nardi, S.; Morari, F. Relationship between soil test phosphorus and phosphorus release to solution in three soils after long-term mineral and manure application. Agric. Ecosyst. Environ. 2016, 233, 214-223. [CrossRef]

15. Nkoa, R. Agricultural benefits and environmental risks of soil fertilization with anaerobic digestates: A review. Agron. Sustain. Dev. 2014, 34, 473-492. [CrossRef]

16. Sheets, J.P.; Yang, L.; Ge, X.; Wang, Z.; Li, Y. Beyond land application: Emerging technologies for the treatment and reuse of anaerobically digested agricultural and food waste. Waste Manag. 2015, 44, 94-115. [CrossRef]

17. Sharpley, A.; Kleinman, P.; Jarvie, H.; Flaten, D. Distant views and local realities: The limits of global assessments to restore the fragmented phosphorus cycle. Agric. Environ. Lett. 2016, 1, 160024. [CrossRef]

18. Möller, K.; Müller, T. Effects of anaerobic digestion on digestate nutrient availability and crop growth: A review. Eng. Life Sci. 2012, 12, 242-257. [CrossRef]

19. Guilayn, F.; Jimenez, J.; Rouez, M.; Crest, M.; Patureau, D. Digestate mechanical separation: Efficiency profiles based on anaerobic digestion feedstock and equipment choice. Bioresour. Technol. 2019, 274, 180-189. [CrossRef]

20. O’Brien, B.J.; Neher, D.A.; Roy, E.D. Nutrient and pathogen suppression properties of anaerobic digestates from dairy manure and food waste feedstocks. Waste Biomass Valor. 2019. [CrossRef]

21. O'Brien, B.J.; Milligan, E.; Carver, J.; Roy, E.D. Integrating anaerobic co-digestion of dairy manure and food waste with cultivation of edible mushrooms for nutrient recovery. Bioresour. Technol. 2019, 285, 121312. [CrossRef]

22. Frear, C. Case Study: DVO Phosphorus Recovery System Edaleen Dairy, Lynden, WA; Newtrient: Rosemont, IL, USA, 2017.

23. Porterfield, K.K.; Faulkner, J.; Roy, E.D. Nutrient recovery from anaerobically digested dairy manure using dissolved air flotation (DAF). ACS Sustain. Chem. Eng. 2020. [CrossRef]

24. Mayer, B.K.; Baker, L.A.; Boyer, T.H.; Drechsel, P.; Gifford, M.; Hanjra, M.A.; Parameswaran, P.; Stoltzfus, J.; Westerhoff, P.; Rittmann, B.E. Total value of phosphorus recovery. Environ. Sci. Technol. 2016, 50, 6606-6620. [CrossRef] [PubMed]

25. Collins, H.P.; Kimura, E.; Frear, C.S.; Kruger, C.E. Phosphorus Uptake by Potato from Fertilizers Recovered from Anaerobic Digestion. Agron. J. 2016, 108, 2036. [CrossRef]

26. Liu, Z.; Howe, J.; Wang, X.; Liang, X.; Runge, T. Use of Dry Dairy Manure Pellets as Nutrient Source for Tomato (Solanum lycopersicum var. cerasiforme) Growth in Soilless Media. Sustainability 2019, 11, 811. [CrossRef]

27. Tao, X.; Shang, B.; Dong, H.; Chen, Y.; Xin, H. Effects of Digestate from Swine Manure Digester on in Vitro Growth of Crop Fungal Pathogens: A Laboratory Study. Trans. ASABE 2014, 57, 1803-1810.

28. Scaglia, B.; Pognani, M.; Adani, F. The anaerobic digestion process capability to produce biostimulant: The case study of the dissolved organic matter (DOM) vs. auxin-like property. Sci. Total Environ. 2017, 589, $36-45$. [CrossRef] [PubMed]

29. Ertani, A.; Pizzeghello, D.; Baglieri, A.; Cadili, V.; Tambone, F.; Gennari, M.; Nardi, S. Humic-like substances from agro-industrial residues affect growth and nitrogen assimilation in maize (Zea mays L.) plantlets. J. Geochem. Explor. 2013, 129, 103-111. [CrossRef]

30. Tambone, F.; Orzi, V.; Zilio, M.; Adani, F. Measuring the organic amendment properties of the liquid fraction of digestate. Waste Manag. 2019, 88, 21-27. [CrossRef]

31. Neher, D.A.; Fang, L.; Weicht, T.R. Ecoenzymes as Indicators of Compost to Suppress Rhizoctonia Solani. Compost Sci. Util. 2017, 25, 251-261. [CrossRef] 
32. Strange, R.N.; Scott, P.R. Plant disease: A threat to global food security. Annu. Rev. Phytopathol. 2005, 43, 83-116. [CrossRef]

33. Miller, R.O.; Gavlak, R.; Horneck, D. Soil, Plant and Water Reference Methods for the Western Region, 4th ed.; Western Coordinating Committee on Nutrient Management: Corvallis, OR, USA, 2013; Available online: https://www.naptprogram.org/files/napt/publications/method-papers/western-statesmethods-manual-2013.pdf (accessed on 21 December 2019).

34. Combs, S.; Hoskins, B.; Jarman, J.; Kovar, J.; Watson, M.; Wolf, A.; Wolf, N. Recommended Methods of Manure Analysis; Peters, J., Ed.; Cooperative Extension Publishing: Madison, WI, USA, 2003; Volume I-2.

35. Brod, E.; Øgaard, A.F.; Haraldsen, T.K.; Krogstad, T. Waste products as alternative phosphorus fertilisers part II: Predicting P fertilisation effects by chemical extraction. Nutr. Cycl. Agroecosyst. 2015, 103, 187-199. [CrossRef]

36. Lajtha, K.; Driscoll, C.T.; Jarrell, W.M.; Elliott, E.T. Soil phosphorus: Characterization and total element analysis. In Standard Soil Methods for Long-Term Ecological Research; Robertson, G.P., Coleman, D.C., Bledsoe, C.S., Sollins, P., Eds.; Oxford University Press: New York, NY, USA, 1999; pp. 115-142.

37. Pantelopoulos, A.; Magid, J.; Jensen, L.S.; Fangueiro, D. Nutrient uptake efficiency in ryegrass fertilized with dried digestate solids as affected by acidification and drying temperature. Plant Soil Dordr. 2017, 421, 401-416. [CrossRef]

38. Green, B.W. Fertilizers in aquaculture. In Feed and Feeding Practices in Aquaculture; Davis, D.A., Ed.; Woodhead Publishing Series in Food Science, Technology and Nutrition; Woodhead Publishing: Oxford, UK, 2015; pp. 27-52, ISBN 978-0-08-100506-4.

39. Reddy, R.K.; DeLaune, R.D. Mineralization of Organic Nitrogen: C:N Ratio Concept. In Biogeochemistry of Wetlands: Science and Applications; CRC Press, Taylor \& Francis Group, LLC: Boca Raton, FL, USA, 2008; pp. 264-267, ISBN 978-1-56670-678-0.

40. Toor, G.S.; Hunger, S.; Peak, J.D.; Sims, T.J.; Sparks, D.L. Advances in the characterization of phosphorus in organic wastes: Environmental and agronomic applications. Adv. Agron. 2006, 89, 1-72.

41. White, P.J.; Brown, P.H. Plant nutrition for sustainable development and global health. Ann. Bot. 2010, 105, 1073-1080. [CrossRef] [PubMed]

42. Maurer, C.; Müller, J. Drying characteristics of biogas digestate in a hybrid waste-heat/solar dryer. Energies 2019, 12, 1294. [CrossRef] 